\title{
PERAN MASYARAKAT DALAM PENDIDIKAN PERSPEKTIF PENDIDIKAN ISLAM
}

\author{
Heru Juabdin Sada \\ herujuabdin@radenintan.ac.id \\ Universitas Islam Negeri Raden Intan Lampung
}

\begin{abstract}
Education is a shared responsibility starting from the government, parents, then the community. Society plays a very important role in the development of children's education. Therefore, the community should participate in participating in children's education activities either directly or indirectly. The implementation of education itself will certainly have an impact on the community itself, thus there is a positive correlation between society and education. The better education is held, the better will be the quality of the community. Vice versa, the better the quality and the better the community, the better and better quality of education held. Therefore, community education must receive serious attention in the system of implementing Islamic education. The results of this study found that the role of the community in Islamic education can improve quality and superior management.
\end{abstract}

Keywords; The Role of Society and Islamic Education.

Abstrak

Pendidikan merupakan tanggungjawab bersama mulai dari pemerintah, orangtua, lalu masyarakat. Masyarakat berperan sangat penting pada perkembangan pendidikan anak. Oleh karena itu, masyarakat hendaknya ikut serta berpartisipasi dalam kegiatan pendidikan anak baik langsung atau tidak langsung. Pelaksanaan pendidikan itu sendiri tentu akan berdampak terhadap masyarakat itu sendiri, dengan begitu terdapat korelasi positif yang bersifat timbalbalik antara masyarakat dan pendidikan. Semakin baik pendidikan diselenggarakan maka akan semakin berkualitas pada masyarakat. Begitu juga sebaliknya, semakin berkualitas dan baik masyarakatnya, semakin baik dan berkualitas pendidikan yang diselenggarakan. Oleh karena itu, pendidikan kemasyarakatan harus mendapat perhatian yang serius dalam sistem penyelenggaraan pendidikan Agama Islam. Hasil dari kajian ini didapatkan bahwa peran masyarakat dalam pendidikan Islam dapat meningkatkan manajemen yang berkualitas dan unggul.

Kata Kunci; Peran Masyarakat dan Pendidikan Islam. 


\section{PENDAHULUAN}

Hakekat pembangunan nasional adalah pembangungan manusia Indonesia seutuhnya dan pembanguan seluruh masyarakat Indonesia. Landasan pembangunan nasional Indonesia adalah pancasila dengan berusaha untuk mewujudkan tujuan nasional yaitu menciptakan masyarakat adil dan makmur. Pendidikan merupakan kunci pembangunan suatu bangsa (Heningtyas, Sjamsuddin, \& Hadi, 2014).

Pendidikan tidak dapat dipisahkan dari kehidupan keluarga, sekolah dan masyarakat. Pendidikan berupaya mendidik manusia untuk mempunyai ilmu pengetahuan dan ketrampilan disertai dengan Iman dan Taqwa kepada Allah SWT, sehingga dia akan memanfaatkan ilmu pengetahuan dan ketrampilan yang dimilikinya itu untuk kebaikan masyarakat, lingkungan dan bangsanya (Djaelani, 2013) .

Tuntutan pengembangan sumber daya pada manusia semakin meningkat, maka layanan pada pendidikan haruslah mampu mengikuti dan mengimbangi perkembangan tersebut. Selain keluarga dan lembaga pendidikan, masyarakat sangat memiliki peran penting terhadap pendidikan.

Masyarakat merupakan istilah yang sangat lazim digunakan untuk menyebut suatu kesatuan-kesatuan manusia yang berasal dari bahasa Arab yaitu Syaraka yang berarti ikut serta, berpartisipasi, yang kemudian mengalami perubahan dalam bahasa Indonesia menjadi masyarakat. Masyarakat adalah suatu kesatuan manusia yang saling berinteraksi menurut suatu sistem adat-istiadat tertentu yang bersifat kontinu dan saling terikat oleh suatu rasa dan identitas yang sama dalam dirinya (Koentjoroningrat, 2000).

Masyarakat adalah sekumpulan orang dengan berbagai ragam kualitas diri mulai dari yang tidak berpendidikan sampai pada yang berpendidikan tinggi. Kualitas suatu masyarakat ditentukan oleh kualitas pendidikan para anggotanya, makin baik pendidikan anggotanya, semakin baik pula kualitas masyarakat secara keseluruhan. Masyarakat merupakan lembaga pendidikan yang ketiga setelah pendidikan di lingkungan keluarga dan lingkungan sekolah (Djaelani, 2013; Hasan, 2010).

Masyarakat berperan sangat penting pada perkembangan pendidikan anak. Oleh karenanya masyarakat hendaknya ikut serta berpartisipasi dalam kegiatan pendidikan anak baik langsung atau tidak langsung. Karena lingkungan dalam keluarga, dan sekolah serta masyarakat sangat memiliki keterikatan. 
Partisipasi dapat didefinisikan sebagai keterlibatan mental/pikiran dan emosi/perasaan seseorang di dalam situasi kelompok yang mendorongnya untuk memberikan sumbangan kepada kelompok dalam usaha mencapai tujuan serta turut bertanggung jawab terhadap usaha yang bersangkutan(Hartono, 2012).

Saat ini partisipasi masyarakat masih sangat terbatas seperti ikut serta jadi anggota masyarakat pada tahap implementasi program pembangunan terutama pada pendidikan.karena sering dipahami sebagai bentuk mobilisasi untuk berbagai kepentingan pemerintah. Perwujudan partisipasi oleh masyarakat dapat juga dilakukan secara individu atau kelompok, spontanitas atau terorganisir, dilakukan secara kontinnyu atau sesaat. Pembangunan yang tidak melibatkan partisipasi masyarakat dalam pelaksanaanya dianggap seringkali tidak menyentuh kebutuhan masyarakat, karena masyarakat adalah pihak yang paling mengetahui yang menjadi permasalahan mereka serta mengerti cara bagaimana mengatasi permasalahan mereka (Heningtyas et al., 2014).

Peran masyarakat dalam pendidikan tercantum dalam Undang-Undang Nomor 20 Tahun 2003 Pasal 8 dan 9 yang menyatakan bahwa masyarakat berhak berperan serta dalam perencanaan, pelaksanaan, pengawasan dan evaluasi program kerja pendidikan serta berkewajiban memberikan dukungan sumber daya dalam penyelenggaraan pendidikan (Lutfiyah, 2013).

Berdasarkan penelitian terdahulu juga diperoleh betapa pentingnya peran masyarakat dalam kehidupan bermasyarakat maupun dalam pendidikan, hal ini sesuai dengan hasil penelitian oleh (Dewita, Zainal, \& H, 2013; Djaelani, 2013; Hartono, 2012; Heningtyas et al., 2014; Ibori, 2013; Laoli, Naria, \& Marsaulina, 2013; Maridi, 2012; Maujud, 2017; Pahabol, 2013; Rahim, 2013; S, 2013; Siswanto, 2013; Sulistyorini, 2011; Susilowati, Damianto, Nadjam, \& Nurhayati, 2012; Umar, 2016; Utami \& Kurniawati, 2013; Wihendra, Wairocana, \& Dahana, 2012).

Berdasarkan paparan di atas maka pembaharuan padapenelitian ini yaitu peneliti akan mengkaji mengenai peran masyarakat dalam pendidikan perspektif pendidikan Islam. 


\section{HASIL KAJIAN DAN PEMBAHASAN}

\section{A. Masyarakat dalam perspektif Pendidikan Islam}

Masyarakat merupakan sekumpulan individu-individuyang kecil atau besar, terikat pada satuan adat istiadat, kebaiasaan atau hukum, dan hidup dalam kebersamaan. Demikian satu contoh dari beraneka macam definisinya. Ada banyak kata yang tertulis dalam Al-Quran yang menunjukan kepada masyarakat. Antara lain: qawm, ummah, syu'ub, dan qabail. Selain itu, Al-Quran juga memperkenalkan kepada masyarakat dengan sifat-sifat tertentu, seperti al-mala', al-mustakbirun, al-mustadh'afun, dan lainlain.

Manusia adalah "makhluk sosial". Ayat kedua dari wahyu pertama yang diterima Nabi Muhammad Saw., dapat dipahami sebagai salah satu ayat yang menjelaskan hal tersebut.Dalam Qs. Al-Alq ayat 2 bukan saja diartikan sebagai "menciptakan manusia dari segumpal darah" atau "sesuatu yang berdempet di dinding rahim", tetapi juga dapat dipahami sebagai "diciptakan dinding dalam keadaan selalu bergantung kepada pihak lain atau tidak dapat hidup sendiri.”Ayat Qur'an yang lain pada konteks ini yaitu surat Al-Hujurat ayat 13.

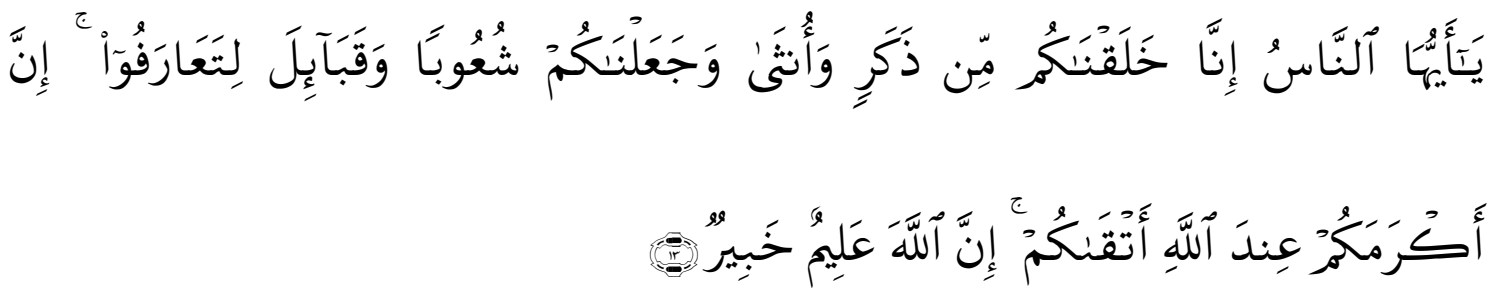

Artinya: "Hai manusia, Sesungguhnya Kami menciptakan kamu dari seorang laki-laki dan seorang perempuan dan menjadikan kamu berbangsa - bangsa dan bersuku-suku supaya kamu saling kenal-mengenal. Sesungguhnya orang yang paling mulia diantara kamu disisi Allah ialah orang yang paling taqwa diantara kamu. Sesungguhnya Allah Maha mengetahui lagi Maha Mengenal”.

Pada ayat tersebut dengan tegas menyatakan bahwa manusia Allah ciptakan dua jenis yaitu laki-laki dan perempuan, terdiri dari banya macam suku dan bangsa, suapaya saling mengenal. Sesungguhnya dapat dikatakan sebagaimana dalam Al-Quran, manusia secara fitrah merupakan makhluk sosial yang hidup dalam masyarakat merupakan kepastian bagi mereka.Kemudian, didalam Qur'an juga ditemukan beberapa bagian 
yang mempunyai kesamaan makna dengan masyarakat. Ali Nurdin, dalam bukunya Quranic Society, menyebutkan ada 12 term yang menunjuk pada masyarakat, yaitu: Qaum, Ummah, Sya'b, Qabilah, Firqah, Thaifah, Hizb, Fauj, suatu ungkapan diawali dengan Ahl, Alu, al-Nas, dan Asbath.

Istilah di atas menunjukkan bahwa sesungguhnya masyarakat mendapatkan perhatian khusus dalam al-Qur'an. Oleh karena itu, setiap individu sebagai anggota masyarakat tertentu harus berupaya untuk mewujudkan kesejahteraan masyarakat dengan sebaik-baiknya dan tertib dalam ridha ilahi serta tetap menjalakan fungsinya sebagai makhluk sosial. Rangka untuk mempertahankan keradaan manusia sebagai masyarakat sosial, sangat diperlukan pendidikan sehingganya interaksi antara sesama pada suatu kelompok masyarakat dapat terjadi secara harmonis.

\section{B. Peran masyarakat dalam pendidikan Perspektif Pendidikan Islam}

Berdasarkan tantangan yang akan dihadapi didalam masyarakat terutama peran pendidikan agama Islam dan peran Undang-Undang Sisdiknas Nomor 20 Tahun 2003, maka bentuk peran serta masyarakat dalam rangka ikut serta meningkatkan pembelajaran pendidikan agama Islam yaitu:

1. Revitalisasi serta reorientasi didalam pendidikan keIslaman terutama pada keluarga dan anggota keluarga merupakan bagian tak terpisakan dari individu-individu masyarakat, serta memiliki peranan dalam masyarakat yang strategis didalam memberikan dorongan terhadap pendidikan agama Islam. Tanggung jawab kedua orang tua sangatlah penting keberlangsungan pendidikan terutama dalam bidang pendidikan keagamaan terhadap semua anggota keluarga dan akan memberikan dampak yang sangat nyata dalam peran meningkatan pendidikan agama dengan memberi contoh atau uswah yang baik terutama berperilaku keagamaan di dalam keluarga, akan menjadi lebih efektif pada proses tercapainya tujuan pendidikan keIslaman yaitu untuk menjadi pribadi yang paripurna.Peranan pada keluarga yang berperan sebagai pendidikan pertama dan utama, adalah peranan yang sangat nyata bagi anggota masyarakat untuk mengembalikan fungsinya sebagai "madrosatul ula". Fungsi-fungsi di dalam setiap anggota keluarga tersebut harus kembali mendapatkan penguatan, baik itu sebagai ayah, sebagai ibu maupun sebagai anak, yang merupakan suatu bagian lingkungan terkecil di masyarakat. 


\section{Penguatan Learning Society}

Salah satu tempat yang potensial pada penguatan learning society yaitu memfungsikan Masjid, Musholla, atau Langgar dan lembaga-lembaga non formal lainnya. Setiap RW memiliki Masjid atau Musholla, yang secara umum mempunyai jama'ah masing-masing (yang terdiri dari anggota masyarakat). Pada kontek ini tempat ibadah seperti Masjid juga telah berfungsi sebagai tempat pembelajaran masyarakat digunakan untuk dapat meningkatkan pengetahuan keislaman. Pusat-pusat pembelajaran di dalam masyarakat masalah agama telah berlangsung di Masjid sejak berabad-abad lalu sampai dengan sekarang. Namun pada era teknologi informasi ini meng-hegemony hampir diseluruh lapisan kehidupan didunia, maka tradisi belajar membaca Al-Quran di masjid, musholla dan langgar pada pada waktu itu berkurang. Jutaan orang masyarakat yang muslim dulu biasa belajar keagamaansetelah shalat magrib sampai shalat Isya. Sekarang sudah beralih ke depan TV, menonton film, sinetron dan atau keliling ke Mall. Selain itu untuk meminimalisir distorsi pemahaman agama pada masyarakat, dapat dipelopori dan dimulai dari gerakan acara di TV dan serta internet sehat, dll.

3. Berpartsipasi aktif dalam Komite Madrasah/Sekolah

Salah satu dari sarana untuk ikut berperan serta di dalam meningkatkan suatu kualitas pendidikan agama adalah masyarakat yang juga dapat ikut berperan aktif di Komite Sekolah/Madrasah sebagaimana yang diatur di dalam pasal 56 UU Sisdiknas No. 20 Tahun 2003, bahwa masyarakat juga dapat ikut berperan aktif dalam peningkatan mutu pelayanan pendidikan yang meliputi yaitu perencanaan, pengawasan dan evaluasi terhadap program pendidikan. Termasuk yang di dalamnya bidang pendidikan agama (Maujud, 2017).

4. Mendorong dan mendukung dalam semua program Pendidikan Agama di madrasah/sekolah;

Peran serta masyakat dalam meningkatkan mutu pendidikan agama juga bisa dapat dilakukan dengan cara mendorong dan mendukung disemua kebijakan yang dilakukan Sekolah/madrasah yang terkait dalam peningkatan suatu mutu pendidikan agama, baik melalui program kegiatan kurikuler, misalnya, dengan adanya jam tambahan khusus untuk jam pelajaran agama (Membaca Al-Qur'an 
setiap harinya pada awal memulai pembelajaran dikelas, seperti di Al-Azhar, di MAN, di MTS, dan Islamic Fullday School, atau dari beberapa sekolah umum lainnya, dan juga membiasakan dengan berbusana Muslim di Sekolah umum juga tentunya dapat mendukung di dalam program-program ekstra, seperti pengamalan ibadah, praktikum Dhuha, bimbingan baca quran, dll.

5. Mendirikan lembaga pendidikan agama yang berbasis mutu

Suatu lembaga pendidikan keagamaan secara umum masih tetap dianggap lembaga pendidikan nomor dua jika dibandingkan dengan sekolah-sekolah umum lainnya. Masalah ini juga yang dapat menjadikanperhatian para pengamat pendidikan Islam, maka wujud nyata peran serta dalam masyarakat sebagai usaha untuk meningkatkan kualitas mutu pendidikan keagamaan yaitu mendirikan serta mengembangkan lembaga-lembaga keagamaan yang bersifat nonforman berbasis mutu keislaman.

\section{SIMPULAN DAN SARAN}

Secara garis besar peningkatan "peran serta" masyarakat di dalam pemberdayaan dan peningkatan pendidikan keagamaan dapat disusun sebagai berikut; Pertama; peningkatan dan peran serta terhadap masyarakat di dalam proses pemberdayaan managemen pendidikan yakni peningkatan dalam pengembangan managemen lebih accountable, dari dalam segi pendanaan maupun didalam organisasi yang ada dalam pendidikan itu sendiri. Melalui peningkatan ini, sumber keuangan masyarakat harus dapat dipertanggungjawabkan atau dikelola secara lebih efisien untuk pemberdayaan pendidikan dan peningkatan kualitas pendidikan terutama pendidikan Islam; begitu juga dari dalam sisi organisasi, sehingga pastinya menjadi lebih visable dan durable di dalam menjadikan perubahan dan tantangan zaman.

Kedua, peningkatan dan peran dalam masyarakat di dalam pengembangan manajemen organisasi pendidikan yang berkualitas serta berkeunggulan, yang terdapat pada saatnya akan menjadikan perkembangan madrasah dan lembaga-lembaga pendidikan Islam lainnya menjadi "centers of exellence " yang menghasilkan pendidik dengan berbagai berparadigma keilmuan "komprehensif", yakni pengetahuan secara umum dan pengetahuan keagamaan, serta imtaq. Ketiga; peningkatan peran di masyarakat di dalam mengatur pengelolaan sumber belajar yang lain yang dapat pada 
kelompok masyarakat, sehingga dengan system pendidikan keIslaman tidak terpisah, bahkan menjadi bagian integral dari dalam masyarakat muslim secara keseluruhan. Melalui pengembangan ini, madrasah atau perguruan lainnya dapat menjadi "core" dari "learning society", masyarakat belajar, yang gilirannya membuat anak didik keluaran lembaga pendidikan Islam lebih berkualitas, capable, fungsional dan integrated dengan masyarakat.

Penghayatan dan pengamalan keagamaan umat Islam dalam masa dua atau tiga dekade terakhir ini sangat jauh lebih maju, semarak dan mantap untuk dibandingkan dengan masa sebelumnya atau dimasa orde lama. Berapapun masih ada kekurangan dan hambatan lainnya, program pendidikan agama telah memberikan hasil dan dampak positif bagi peningkatan suatu kualitas keimanan dan ketaqwaan generasi muda dan umat Islam Indonesia.

Kesadaran masyarakat agar untuk menanamkan keimanan dan ketaqwaan sedini mungkin kepada anak-anak didik kita makin tumbuh dan merata.Hal tersebut dapat dilihat dari semakin maraknya kegiatan "pendidikan agama". Melalui media masa, munculnya pengajian-pengajian, majlis ta'lim, madrasah diniyah, pesantren kilat, taman pendidikan Al Qur'an, dan lain-lain.

\section{DAFTAR PUSTAKA}

Dewita, Zainal, S., \& H, U. N. (2013). Peran Serta Masyarakat Desa Semuntai Dalam Pelaksanaan Program Community Development. Jurnal Hutan Lestari, 1(1), 4451.

Djaelani, S. (2013). Peran Pendidikan Agama Islam Dalam Keluarga Dan Masyarakat. Jurnal Ilmiah WIDYA, 1(2), 100-105.

Hartono. (2012). Peran Penting Masyarakat Dalam Partisipasi Peningkatan Mutu Pendidikan Agama Islam Di Madrasah. Al Hikmah, 2(2), 105-124.

Hasan, M. (2010). Tujuan Penciptaan Manusia Dan Fungsi Lembaga-Lembaga Pendidikan. Jurnal Hunafa, 7(1), 107-120.

Heningtyas, M. A., Sjamsuddin, S., \& Hadi, M. (2014). Peran Pemerintah Dan Masyarakat Dalam Upaya Pengembangan Pendidikan Nonformal (Studi Kasus: Eksistensi "Kampung Inggris" Kabupaten Kediri). Jurnal Administrasi Publik (JAP), 2(2), 264-268.

Ibori, A. (2013). Partisipasi Masyarakat Dalam Pelaksanaan Pembangunan Di Desa 
Tembuni Distrik Tembuni Kabupaten Teluk Bintuni. GOVERNANCE, 5(1).

Koentjoroningrat. (2000). Pengantar Ilmu Antropologi. Jakarta: Rineka Cipta.

Laoli, R. F., Naria, E., \& Marsaulina, I. (2013). Peran Serta Masyarakat Dalam Pengadaan Sarana Air Bersih Di Desa Lasara Idanoi Kecamatan Gido Kabupaten Nias. Jurnal Lingkungan Dan Keselamatan Kerja, 2(3), 1-7.

Lutfiyah, M. (2013). Peran Masyarakat Dalam Memajukan Pendidikan Di Madrasah Ibtidaiyyah Selopajang 02 Desa Selopajang Timur Kecamatan Blado Kabupaten Batang. Universitas Negeri Semarang.

Maridi. (2012). Peran Serta Masyarakat Dalam Pengelolaan Daerah Aliran Sungai Keduang Wonogiri Indonesia. Prosiding Seminar Biologi, 9(1), 452-459.

Maujud, F. (2017). Peran Partisipasi Masyarakat Dalam Meningkatkan Mutu Pendidikan Madrasah (Studi Kasus Di Madrasah Ibtidaiyah Islahul Muta'allim Pagutan Kota Mataram). Palapa: Jurnal Studi Keislaman Dan Ilmu Pendidikan, 5(2), 92-121.

Pahabol, W. (2013). Peran Masyarakat Dalam Melaksanakan Pembangunan Di Distrik Holuwon Kabupaten Yahukimo. GOVERNANCE, 5(1).

Rahim, H. A. (2013). Peran Tokoh Masyarakat Dalam Membentuk Perilaku Memilih Pada Pemilukada Kota Ternate Tahun 2010. GOVERNANCE, 5(1).

S, M. R. P. (2013). Peran Serta Masyarakat Dalam Pengelolaan Sampah Di Kelurahan Pedurungan Kidul Semarang. Journal of Politic and Government Studies, 2(1).

Siswanto. (2013). Partisipasi Masyarakat Dalam Pendidikan Islam (Peran Komite Sekolah/Madrasah). INSANIA, 18(1), 135-144.

Sulistyorini. (2011). Peranserta Masyarakat dalam Pengembangan Sekolah Dasar. Jurnal Pendidikan Dan Pembelajaran, 18(2), 180-187.

Susilowati, W., Damianto, B., Nadjam, A., \& Nurhayati, I. (2012). Peran Serta Masyarakat Dalam Meningkatkan Kualitas Lingkungan Daerah Aliran Sungai Ciliwung. POLI-TEKNOLOGI, 11(1).

Umar. (2016). Partisipasi Masyarakat Dalam Peningkatan Mutu Pendidikan Agama Islam Di Madrasah Ibtidaiyah Miftahul Falah Batur 01, Batur Wetan, Kecamatan Getasan, Kabupaten Semarang Tahun 2016. Institut Agama Islam Negeri (IAIN) Salatiga.

Utami, N., \& Kurniawati, W. (2013). Studi Bentuk Peran Serta Masyarakat Dalam Revitalisasi Kawasan Pecinan Semarang. Jurnal Ruang, 1(1).

Wihendra, I. B. A., Wairocana, I. G. N., \& Dahana, C. D. (2012). Peran Serta Masyarakat Daerah Bantaran Sungai Badung Dalam Penanganan Dan Pengelolaan Sampah Di Wilayah Kota Denpasar. Kertha Wicara, 1(1), 1-8. 